\title{
PENGARUH PEMAHAMAN AKUNTANSI, PEMANFAATAN SISTEM INFORMASI AKUNTANSI DAN SISTEM PENGENDALIAN INTERN TERHADAP KUALITAS LAPORAN KEUANGAN
}

\author{
Ni Luh Wayan Tiya Lestari* dan Ni Nyoman Sri Rahayu Trisna Dewi \\ Sekolah Tinggi Ilmu Ekonomi Triatma Mulya Badung, Bali-Indonesia \\ *tiyalestari5@gmail.com
}

DiPublikasi: 01/01/2020

http://dx.doi.org/10.22225/kr.11.2.1435.170-178

\begin{abstract}
This research aims to test the influence of understanding of accounting, the accounting information system utilization, and internal control systems on the quality of finansial statement. The grand theory used in this research is decision-usefulness theory. The population in this research were all employees at the Regional Financial and Asset Management Agency (BPKAD) of Badung. This research uses non-probability sampling technique that is purposive sampling with the respondents totaled 60 people. The data used were the primary data. The data were collected through questionnaire. The data were analyzed using the multiple linear regression analysis assisted with the SPSS 20 software for windows. The result of this research indicated that the influence of understanding of accounting, the accounting information system utilization, and internal control systems have a partial and simultaneous effect on the quality of finansial statement.
\end{abstract}

Keywords: Understanding of accounting; utilization of accounting information systems; internal control systems; quality of financial statements

Abstrak

Penelitian ini bertujuan untuk mengetahui pengaruh pemahaman akuntansi, pemanfaatan sistem informasi akuntansi, dan sistem pengendalian intern terhadap kualitas laporan keuangan. Grand theory yang digunakan dalam penelitian ini adalah teori kegunaan-keputusan (decision-usefulness theory). Populasi dalam penelitian ini adalah seluruh pegawai pada Badan Pengelolaan Keuangan dan Aset Daerah (BPKAD) Kabupaten Badung. Penelitian ini menggunakan teknik non probability sampling yaitu purposive sampling dengan jumlah responden sebanyak 60 orang. Data yang digunakan adalah data primer. Teknik analisis data yang digunakan dalam penelitian ini adalah regresi linier berganda dengan menggunakan bantuan software SPSS 20 for windows. Hasil penelitian ini menunjukkan bahwa pemahaman akuntansi, pemanfaatan sistem informasi akuntansi, dan sistem pengendalian intern berpengaruh secara parsial dan simultan terhadap kualitas laporan keuangan.

Kata Kunci: Pemahaman akuntansi; pemanfaatan sistem informasi akuntansi; sistem pengendalian intern; kualitas laporan keuangan

\section{PENDAhUluAN}

Meningkatnya tuntutan masyarakat terhadap penyelenggaraan pemerintahan yang baik, telah mendorong pemerintah pusat dan pemerintah daerah untuk menerapkan akuntabilitas publik. Dalam rangka mewujudkan tata kelola yang baik, pemerintah daerah harus terus melakukan upaya untuk meningkatkan transparasi dan akuntabilitas pengelolaan keuangan daerah. Laporan keuangan merupakan media bagi sebuah entitas, dalam hal ini pemerintah untuk mempertanggungjawabkan kinerja keuangannya kepada publik. Pemerintah harus mampu menyajikan laporan keuangan yang mengandung informasi yang berkualitas. Dalam Standar Akuntansi Pemerintahan (SAP) dijelaskan bahwa laporan keuangan yang berkualitas itu harus memenuhi karakteristik relevan, andal, dapat dibandingkan, dan dapat dipahami.

Struktur pemerintahan daerah, khususnya Badan Pengelola Keuangan dan Aset Daerah (BPKAD) merupakan entitas akuntansi yang mempunyai kewajiban melakukan pencatatan atas transaksi-transaksi pendapatan, belanja, dan aset yang terjadi di lingkungan SKPD. Dalam dunia pemerintahan, setiap bagian harus diisi oleh orang yang tepat. Begitu juga pada bagian keuangan yang harus diisi oleh sumber daya manusia yang memiliki kompetensi dalam memahami akuntansi dan ilmu-ilmu keuangan yang terkait lainnya. Pemahaman akuntansi berpengaruh signifikan positif terhadap kualitas laporan keuangan pemerintah daerah (Diani, 2014). Selain pemahaman akuntansi, pemanfaatan teknologi informasi juga dapat meningkatkan kualitas 
laporan keuangan pemerintah daerah. Dalam rangka mewujudkan akuntabilitas dan transparasi dalam pengelolaan keuangan daerah, penggunaan teknologi informasi merupakan suatu kebutuhan yang harus dipenuhi, untuk membantu pengelolaan data yang lebih cepat, efektif, dan efisien. Tingginya kualitas laporan keuangan pemerintah daerah juga ditentukan oleh seberapa baik sistem pengendalian intern yang dimiliki pemerintah daerah. Pengendalian intern yang lemah menyebabkan sulitnya mendeteksi kecurangan/ketidakakuratan proses akuntansi sehingga bukti audit yang diperoleh dari data akuntansi menjadi tidak kompeten (Winidyaningrum \& Rahmawati, 2009).

Badan Pemeriksaan Keuangan (BPK) mengungkapkan pengawasan internal di pemerintahan provinsi maupun kabupaten/kota di Bali oleh inspektorat masing-masing, dirasakan masih sangat lemah. Akibatnya, banyak penyimpangan dalam pengelolaan anggaran yang lolos begitu saja. Contohnya dalam kasus pengadaan barang dan jasa di Porprov Bali. Banyak yang menjadi temuan kemahalan oleh Badan Pemeriksaan Keuangan (BPK), tetapi malah hal itu tidak menjadi temuan dan atensi pencegahan inspektorat. BPK juga mengkritisi lemahnya pengawasan internal oleh jajaran inspektorat di Bali. Padahal, inspektorat berperan penting dalam mengawasi dan mencegah penyimpangan dalam penyelenggaraan pemerintahan maupun pelaksanaan APBD.

Kabupaten Badung merupakan salah satu kabupaten di Provinsi Bali yang mendapat opini Wajar Tanpa Pengecualian (WTP) dari Badan Pemeriksaan Keuangan (BPK). Badan Pemeriksaan Keuangan (BPK) Perwakilan Bali telah melaksanakan pemeriksaan entrim I dan entrim II terhadap Laporan Keuangan Pemerintah Daerah (LKPD) Kabupaten Badung pada Tahun 2016. Dalam pemeriksaan tersebut, Badung meraih opini WTP (Wajar Tanpa Pengecualian) dari BPK. Namun, opini wajar tanpa pengecualian yang diberikan BPK terhadap laporan keuangan tersebut bukan berarti bebas dari kesalahan dan kelemahan. BPK perwakilan Bali menemukan beberapa permasalahan yakni dalam pencatatan dan pelaporan asset yang belum jelas, pendapatan restribusi daerah, pendapatan atas sewa belum diatur, penerimaan daerah, penatausahaan aset tetap, realisasi belanja dan BPK juga menekankan agar perangkat daerah melaksanakan kepatuhan terhadap aturan yang berlaku serta melaksanakan sistem pengendalian internal. Berdasarkan fenomena tersebut dapat dinyatakan bahwa laporan keuangan pemerintah daerah masih belum seluruhnya memenuhi karakteristik kualitatif yang disyaratkan, sehingga diperlukan pembenahan terhadap sistem kerja pada pegawai pemerintah daerah terutama pada bagian penatausahaan keuangan agar kualitas informasi laporan keuangan yang dihasilkan bermanfaat serta bernilai akurat. Berdasarkan uraian tersebut, motivasi peneliti untuk melakukan penelitian ini adalah untuk menguji pengaruh variabel pemahaman akuntansi, pemanfaatan sistem informasi akuntansi, dan sistem pengendalian intern terhadap kualitas laporan keuangan pemerintah daerah.

Berdasarkan latar belakang yang telah disampaikan, penelitian ini menganalisis pemahaman akuntansi berpengaruh terhadap kualitas laporan keuangan, pengaruh pemanfaatan sistem informasi akuntansi terhadap kualitas laporan keuangan, pengaruh sistem pengendalian intern terhadap kualitas laporan keuangan dan pemahaman akuntansi, pemanfaatan sistem informasi akuntansi, dan sistem pengendalian intern berpengaruh secara simultan terhadap kualitas laporan keuangan di Badan Pengelola Keuangan dan Aset Daerah Kabupaten Badung.

\section{TINJAUAN PUSTAKA}

\section{Teori Kegunaan-Keputusan (Decision-Usefulness Theory)}

Teori kegunaan-keputusan informasi akuntansi merupakan bagian dari teori normatif. Orang pertama yang menggunakan paradigma kegunaan keputusan (decision-usefulness theory) adalah Chambers. Pendekatan model keputusan ditujukan untuk mengetahui informasi apa yang diperlukan untuk membuat keputusan. Teori kegunaan-keputusan mencakup mengenai syarat dari kualitas informasi akuntansi yang berguna dalam keputusan yang akan diambil oleh pengguna informasi akuntansi. Kegunaankeputusan informasi akuntansi mengandung komponen-komponen yang perlu dipertimbangkan oleh penyaji informasi akuntansi agar cakupan yang ada dapat memenuhi kebutuhan para pengambil keputusan yang akan menggunakannya. Premis dari teori kegunaankeputusan meliputi tujuan akuntansi untuk menyediakan informasi keuangan mengenai organisasi guna pengambilan keputusan. Tujuan akuntansi dikaitkan dengan stakeholder yaitu menyediakan informasi keuangan mengenai suatu 

terhadap Kualitas Laporan Keuangan

\begin{abstract}
organisasi yang akan digunakan dalam pembuatan keputusan. Sikap manajemen terhadap penerapan standar akuntansi berhubungan dengan kepentingannya terhadap pengungkapan informasi akuntansi yang menggambarkan kinerja finansial dalam bentuk pelaporan keuangan. Teori kegunaan-keputusan informasi akuntansi tercermin dalam bentuk kaidah-kaidah yang harus dipenuhi oleh komponen-komponen pelaporan keuangan agar dapat bermanfaat dalam rangka pengambilan keputusan ekonomi.
\end{abstract}

\section{Kualitas Laporan Keuangan}

Berdasarkan Peraturan Pemerintah Nomor 71 Tahun 2010, laporan keuangan merupakan laporan terstruktur mengenai laporan posisi keuangan dan transaksi-transaksi yang dilakukan oleh suatu entitas pelaporan. Dalam Peraturan Pemerintah No 8 Tahun 2006, tentang pelaporan keuangan dan kinerja instansi pemerintah, menyatakan bahwa laporan keuangan adalah bentuk pertanggungjawaban pengelolaan keuangan negara dan daerah selama satu periode. Laporan keuangan yang berkualitas menunjukkan bahwa kepala daerah bertanggungjawab sesuai dengan wewenang yang dilimpahkan kepadanya dalam pelaksanaan tanggungjawab mengelola organisasi. Laporan keuangan daerah merupakan pertanggungjawaban pelaksanaan anggaran pendapatan belanja daerah. Suatu laporan keuangan dapat memberi manfaat bagi para pemakainya maka laporan keuangan tersebut harus mempunyai nilai informasi yang berkualitas dan berguna dalam pengambilan keputusan. Kualitas laporan keuangan dapat tercermin dari karakteristik kualitatif.

\section{Pemahaman Akuntansi}

Pemahaman berasal dari kata paham yang mempunyai arti mengerti benar, sedangkan pemahaman merupakan proses pembuatan cara memahami atau memahamkan. Paham menurut Kamus Umum Bahasa Indonesia (Poerwadaminta, 2006) mempunyai pengertian pandai dan mengerti benar, sedangkan pemahaman adalah proses, cara, perbuatan memahami atau memahamkan. Orang yang memiliki pemahaman akuntansi adalah orang yang pandai dan mengerti benar tentang akuntansi.

\section{Pemanfaatan Sistem Informasi Akuntansi}

Sistem informasi akuntansi merupakan seperangkat komponen yang saling berhubungan yang berfungsi mengumpulkan, memproses, menyimpan, dan medistribusikan informasi untuk mendukung pembuatan keputusan dan pengawasan dalam organisasi (Laudon \& Laudon, 2000). Akuntansi dan sistem informasi akuntansi bertolak dari suatu landasan yang terdiri dari berbagai konsep, yaitu konsep mengenai akuntansi itu sendiri, konsep sistem, konsep informasi, konsep organisasi dan konsep pengambilan keputusan (Afifah, 2009).

\section{Sistem Pengendalian Intern}

Pengendalian intern didefinisikan sebagai suatu proses yang dipengaruhi oleh sumber daya manusia dan sistem teknologi informasi yang dirancang untuk membantu organisasi mencapai suatu tujuan tertentu. Menurut Peraturan Pemerintah Nomor 60 Tahun 2008, sistem pengendalian intern pemerintah adalah proses yang integral pada tindakan dan kegiatan yang dilakukan secara terus menerus oleh pimpinan dan seluruh pegawai untuk memberikan keyakinan memadai atas tercapainya tujuan oraganisasi melalui kegiatan yang efektif dan efisien, keandalan pelaporan keuangan, pengamanan aset Negara, dan ketaatan terhadap peraturan perundang-undangan.

\section{Pengembangan Hipotesis}

Pengaruh Pemahaman Akuntansi Terhadap Kualitas Laporan Keuangan

Seseorang dikatakan paham terhadap akuntansi apabila pandai dan mengerti bagaimana proses akuntansi itu dilakukan sampai menjadi suatu laporan keuangan dengan berpedoman pada prinsip dan standar penyusunan laporan keuangan yang diterapkan. (Yuliani, Nadirsyah, \& Bakar, 2010) telah melakukan penelitian pada pemerintah kota Banda Aceh, menyatakan bahwa untuk dapat menghasilkan laporan keuangan yang berkualitas maka kualitas orang-orang yang melaksanakan tugas dalam menyusun laporan keuangan harus menjadi perhatian utama yaitu para pegawai yang terlibat dalam aktivitas tersebut harus mengerti dan memahami bagaimana proses dan pelaksanaan akuntansi itu dijalankan dengan berpedoman pada ketentuan yang berlaku. Hal tersebut didukung oleh penelitian (Diani, 2014) yang menyatakan pemahaman akuntansi berpengaruh signifikan positif terhadap kualitas laporan keuangan. Jadi dapat disimpulkan bahwa semakin baik pemahaman akuntansi maka semakin baik kualitas laporan keuangan pemerintah daerah 

terhadap Kualitas Laporan Keuangan

tersebut. Sehingga hipotesis dalam penelitian ini adalah:

H1 : Pemahaman akuntansi berpengaruh terhadap kualitas laporan keuangan.

Pengaruh Pemanfaatan Sistem Informasi Akuntansi Terhadap Kualitas Laporan Keuangan

Untuk terselenggaranya proses penyampaian informasi yang cepat dan akurat sehingga dapat menghasilkan laporan keuangan yang baik, pemerintah pusat dan daerah berkewajiban untuk mengembangkan dan memanfaatkan kemajuan teknologi informasi. Semakin baik pemanfaatan sistem informasi akuntansi, maka kualitas laporan keuangan yang dihasilkan akan semakin meningkat. Dalam penelitian (Silviana, 2014) pada pemerintah kabupaten di seluruh Jawa Barat, menunjukkan bahwa sistem informasi keuangan daerah berpengaruh signifikan positif terhadap kualitas laporan keuangan. Sehingga hipotesis dalam penelitian ini adalah:

H2 : Pemanfaatan sistem informasi akuntansi berpengaruh terhadap kualitas laporan keuangan.

Pengaruh Sistem Pengendalian Intern Terhadap Kualitas Laporan Keuangan

Pengendalian intern merupakan suatu cara untuk mengarahkan, mengevaluasi, dan mengukur sumber daya yang dimiliki suatu organisasi, serta berperan penting dalam pencegahan dan pendeteksian adanya penggelapan dan kecurangan. Penelitian (Artana, 2016) membuktikan secara empiris bahwa pengendalian intern berpengaruh signifikan positif terhadap kualitas laporan keuangan. Hasil penelitian (Saputra, Satriawan, \& Supriono, 2015) pada satuan perangkat daerah kabupaten Kambar menunjukkan bahwa sistem pengendalian intern berpengaruh terhadap kualitas laporan keuangan. Sehingga hipotesis dalam penelitian ini adalah:

H3 : Sistem pengendalian intern berpengaruh terhadap kualitas laporan keuangan.

Pengaruh Pemahaman Akuntansi, Pemanfaatan Sistem Informasi Akuntansi, dan Sistem Pengendalian Intern Terhadap Kualitas Laporan Keuangan

Rendahnya kualitas laporan keuangan dapat disebabkan oleh pemahaman akuntansi penyusun laporan keuangan itu sendiri, belum diterapkannya secara optimal sistem informasi akuntansi keuangan daerah dan lemahnya peran internal audit. Dalam penelitian (Mardiana \& Fahlevi, 2017) menunjukkan bahwa pemahaman akuntansi dan pengendalian intern secara bersama -sama berpengaruh terhadap kualitas laporan keuangan pemerintah. Penelitian (Silviana, 2014) menunjukkan bahwa penerapan sistem informasi akuntansi berpengaruh terhadap kualitas laporan keuangan pemerintah daerah.

H4 : Pemahaman akuntansi, pemanfaatan sistem informasi akuntansi, dan sistem pengendalian intern berpengaruh terhadap kualitas laporan keuangan.

\section{METODE}

\section{Tempat, Populasi dan Metode Penentuan Sampel}

Penelitian ini dilakukan pada Badan Pengelola Keuangan dan Aset Daerah (BPKAD) Kabupaten Badung. Populasi dalam penelitian ini adalah seluruh pegawai pada Badan Pengelola Keuangan dan Aset Daerah (BPKAD) Kabupaten Badung yang berjumlah 108 responden. Alasan pemilihan sampel di BPKAD Kapupaten Badung adalah karena BPKAD merupakan satuan kerja yang melakukan konsolidasi laporan keuangan semua SKPD dalam lingkup kabupaten/kota dan menghasilkan output akhir berupa laporan keuangan pemerintah kabupaten/kota dalam rangka pelaksanaan dan pertanggungjawaban APBD Kabupaten Badung. Sampel dalam penelitian ini berjumlah 60 responden. Metode pengumpulan data yang digunakan adalah dengan menggunakan kuesioner. Teknik pengambilan sampel dalam penelitian ini menggunakan teknik Purposive sampling dimana sampel dipilih atas kriteria-kriteria tertentu. Adapun kriteria-kriteria pengambilan sampel dalam penelitian ini adalah pekerja pada bagian pengelolaan keuangan dan pekerja yang lebih dari satu tahun.

\section{Definisi Operasional Variabel dan Pengukurannya}

Pemahaman Akuntansi (X1)

Paham terhadap akuntansi yaitu pandai dan mengerti bagaimana proses akuntansi itu dilakukan sampai menjadi suatu laporan keuangan dengan berpedoman pada prinsip dan standar penyusunan laporan keuangan yang telah ditetapkan. Variabel ini menggunakan 10 item pernyataan dengan menggunakan instrumen yang dikembangkan oleh (Artana, 2016).

\section{Pemanfaatan Sistem Informasi Akuntansi (X2)}

Sistem informasi akuntansi merupakan seperangkat komponen yang saling berhubungan yang berfungsi mengumpulkan, memproses, menyimpan, dan mendistribusikan informasi untuk mendukung pembuatan keputusan dan pengawasan dalam organisasi. Variabel ini 

terhadap Kualitas Laporan Keuangan

\begin{abstract}
menggunakan 10 item pernyataan dengan menggunakan instrumen yang dikembangkan oleh (Artana, 2016).

Sistem Pengendalian Intern (X3)

Pengendalian intern merupakan suatu cara untuk mengarahkan, mengevaluasi, dan mengukur sumber daya yang dimiliki suatu organisasi, serta berperan penting dalam pencegahan dan pendeteksian adanya penggelapan dan kecurangan. Variabel ini menggunakan 20 item pernyataan dengan menggunakan instrumen yang dikembangkan oleh (Artana, 2016).

\section{Kualitas Laporan Keuangan (Y)}

Laporan keuangan merupakan laporan terstruktur mengenai laporan posisi keuangan dan transaksi-transaksi yang dilakukan oleh suatu entitas pelaporan. Laporan keuangan yang berkualitas menunjukkan bahwa kepala daerah bertanggungjawab sesuai dengan wewenang yang dilimpahkan kepadanya dalam pelaksanaan tanggungjawab mengelola organisasi. Variabel ini menggunakan 9 item pernyataan dengan menggunakan instrumen yang dikembangkan oleh (Artana, 2016).

\section{Teknik Analisis Data}

Penelitian ini menggunakan metode analisis data Regresi Linier Berganda dengan bantuan software SPSS 20 for Windows. Sebelum dilakukan analisis regresi linier berganda, terlebih dulu dilakukan uji kualitas data yang terdiri dari uji validitas dan reliabilitas, kemudian dilanjutkan dengan uji asumsi klasik yang terdiri dari uji normalitas, uji multikolinieritas dan uji heteroskedastisitas.

\section{Analisis Regresi Linier Berganda}

Analisis regresi linier berganda adalah hubungan secara linier antara dua atau lebih variabel independen $(\mathrm{X} 1, \mathrm{X} 2, \mathrm{X} 3, \ldots \mathrm{Xn})$ dengan variabel dependen $(\mathrm{Y})$. Dengan persamaan:

$$
\begin{aligned}
& \mathrm{Y}=\mathrm{a}+\beta 1 \mathrm{X} 1+\beta 2 \mathrm{X} 2+\beta 3 \mathrm{X} 3+ \\
& \text { e................. } \\
& \text { Keterangan: } \\
& \mathrm{Y} \quad=\text { Kualitas laporan keuangan } \\
& \mathrm{X}_{1} \quad=\text { Pemahaman Akuntansi } \\
& \mathrm{X}_{2} \quad=\quad \text { Pemanfaatan sistem informasi } \\
& \text { akuntansi } \\
& \mathrm{X}_{3} \quad=\text { Sistem pengendalian intern } \\
& \mathrm{a} \quad=\text { Nilai konstan }
\end{aligned}
$$

$$
\begin{aligned}
& \mathrm{B} \quad=\text { Koefisien regresi } \\
& \mathrm{E} \quad=\text { Kesalahan pengganggu (disturbance's } \\
& \text { error) } \\
& \text { Uji Statistikt }
\end{aligned}
$$

Uji statistik $\mathrm{t}$ bertujuan untuk menguji seberapa jauh pengaruh satu variabel independen secara individual dalam menerangkan variasi variabel dependen (Sudaryono, 2017). Adapun kriteria pengujiannya adalah sebagai berikut; 1) Tingkat probabilitas (sig.) $\mathrm{t} \leq \alpha / 2=0,025$; Hi diterima dan $\mathrm{H} 0$ ditolak dan 2) Tingkat probabilitas (sig.) $\mathrm{t}>\alpha / 2=0,025$; Hi ditolak dan H0 diterima.

\section{Uji Statistik F}

Uji statistik F dilakukan dengan tujuan untuk menguji apakah semua variabel independen yang dimaksud dalam model mempunyai pengaruh secara bersama-sama terhadap variabel dependen (Ghozali, 2013). Adapun kriteria pengujiannya adalah sebagai berikut; 1) Tingkat probabilitas (sig.) $\mathrm{F} \leq \alpha=0,05$; Hi diterima dan $\mathrm{H} 0$ ditolak dan 2)Tingkat probabilitas (sig.) $\mathrm{F}>\alpha=0,05$; Hi ditolak dan $\mathrm{H} 0$ diterima.

\section{Koefisien Determinasi}

Koefisien determinasi mengukur seberapa jauh kemampuan model dalam menerangkan variasi variabel dependen (Ghozali, 2013). Nilai koefisien determinasi ditunjukkan dengan nilai adjusted R Square bukan R Square dari model regresi karena $R$ Square bias terhadap jumlah variabel dependen yang dimasukkan ke dalam model, sedangkan adjusted $\mathrm{R}$ Square dapat naik turun jika suatu variabel independen ditambahkan dalam model (Ghozali, 2013).

\section{HASIL DAN PEMBAHASAN}

\section{Gambaran Umum Responden}

Pengembalian Kuesioner

Penyebaran kuesioner dilakukan pada seluruh pegawai bagian keuangan di BPKAD Kabupaten Badung. Keseluruhan kuesioner yang disebar adalah sebanyak 60 kuesioner. Dari seluruh kuesioner yang disebar oleh peneliti, jumlah kuesioner yang kembali adalah berjumlah 60 kuesioner atau $100 \%$ dan kuesioner yang tidak kembali 0 atau $0 \%$. Kuesioner yang dapat diolah berjumlah 60 kuesioner atau 100\% dan kuesioner yang tidak dapat diolah berjumlah 0 atau $0 \%$.

Karakteristik Responden

Dari hasil pengumpulan sampel dapat 
dijelaskan bahwa responden responden dalam penelitian ini sebagian besar berjenis kelamin perempuan yaitu berjumlah 38 orang atau sebesar $63 \%$ dan yang berjenis kelamin laki-laki berjumlah 22 orang atau sebesar $37 \%$. Mayoritas responden yang bekerja pada BPKAD Kabupaten Badung berusia 41-50 tahun yaitu sebanyak 25 responden atau 42\%. Mayoritas responden dalam penelitian ini sebanyak 26 pegawai atau $43 \%$ memiliki masa kerja sekitar 11-20 tahun, sedangkan sisanya sebanyak 20 pegawai atau 34\% memiliki masa kerja 6-10 tahun, dan sekitar 14 pegawai atau $23 \%$ memiliki masa kerja lebih dari 20 tahun dan seluruh responden sebanyak 60 pegawai atau $100 \%$ berstatus PNS.

\section{Uji Kualitas Data}

\section{Uji Validitas}

Berdasarkan uji validitas yang telah dilakukan hasil perhitungan nilai korelasi yang ditunjukkan dengan nilai Pearson Correlation dari tiap butir pernyataan diperoleh hasil seluruhnya $>0,30$. Hal ini berarti bahwa instrumen yang digunakan dalam penelitian ini adalah valid.

\section{Uji Relabilitas}

Untuk uji reliabilitas yang ditunjukkan dengan nilai Cronbach Alpha dari masing-masing variabel diperoleh hasil yang besarnya $>0,6$. Hal ini menunjukkan bahwa instrumen yang digunakan dalam penelitian ini adalah reliabel.

\section{Uji Asumsi Klasik}

Uji Normalitas

Tabel 1

Hasil Pengujian Normalitas

\begin{tabular}{ccc}
\hline Variabel & $\begin{array}{c}\text { Asymp. Sig } \\
\text { (2-tailed) }\end{array}$ & Keterangan \\
\hline Pemahaman Akuntansi $\left(\mathrm{X}_{1}\right)$ & 0,709 & Normal \\
Pemanfaatan Sistem Informasi Akuntansi $\left(\mathrm{X}_{2}\right)$ & 0,600 & Normal \\
Sistem Pengendalian Intern $\left(\mathrm{X}_{3}\right)$ & 0,596 & Normal \\
Kualitas Laporan Keuangan $(\mathrm{Y})$ & 0,497 & Normal \\
\hline
\end{tabular}

Berdasarkan hasil pengujian pada Tabel 1 diketahui bahwa nilai Asymp Sig (2-tailed) seluruh variabel lebih dari 0,05 , sehingga dapat

disimpulkan bahwa data yang digunakan dalam penelitian ini berdistribusi normal.

Uji Multikolinearitas

Tabel 2

Hasil Pengujian Multikolinearitas

\begin{tabular}{cccc}
\hline Variabel & Tolerance & VIF & Keterangan \\
\hline Pemahaman Akuntansi $\left(\mathrm{X}_{1}\right)$ & 0,826 & 1,211 & Tidak terjadi multikolinearitas \\
Pemanfaatan Sistem Informasi Akuntansi $\left(\mathrm{X}_{2}\right)$ & 0,832 & 1,202 & Tidak terjadi multikolinearitas \\
Sistem Pengendalian Intern $\left(\mathrm{X}_{3}\right)$ & 0,860 & 1,163 & Tidak terjadi multikolinearitas \\
\hline Berdasarkan Tabel 2, dapat dilihat bahwa nilai & tidak terjadi multikolinearitas antar variabel yang \\
tolerance dari masing-masing variabel & digunakan dalam penelitian ini. \\
independen berada diatas 0,10 dan nilai VIF & Uji Heteroskedastisitas
\end{tabular}

Tabel 3

Hasil Pengujian Heteroskedastisitas

\begin{tabular}{ccc}
\hline Variabel & Sig & Keterangan \\
\hline Pemahaman Akuntansi $\left(\mathrm{X}_{1}\right)$ & 0,396 & Tidak terjadi heteroskedastisitas \\
Pemanfaatan Sistem Informasi Akuntansi $\left(\mathrm{X}_{2}\right)$ & 0,901 & Tidak terjadi heteroskedastisitas \\
Sistem Pengendalian Intern $\left(\mathrm{X}_{3}\right)$ & 0,424 & Tidak terjadi heteroskedastisitas \\
\hline
\end{tabular}

Hasil uji heteroskedastisitas menunjukkan bahwa masing-masing variabel mempunyai nilai signifikan berada diatas atau sama dengan 0,05 , sehingga dapat disimpulkan bahwa data yang digunakan dalam penelitian ini bebas dari heteroskedastisitas.
Analisis regresi linier berganda adalah hubungan secara linier antara dua atau lebih variabel independen dengan variabel dependen (Y). Hasil pengolahan data dengan bantuan software SPSS 20.0 for windows. 
Pengaruh Pemahaman Akuntansi, Pemanfaatan Sistem Informasi Akuntansi dan Sistem Pengendalian Intern terhadap Kualitas Laporan Keuangan

Tabel 4

Hasil Analisis Regresi Linier Berganda

\begin{tabular}{|c|c|c|c|c|c|}
\hline \multicolumn{6}{|c|}{ Coefficients ${ }^{\mathrm{a}}$} \\
\hline \multirow[t]{2}{*}{ Model } & \multicolumn{2}{|c|}{$\begin{array}{l}\text { Unstandardized } \\
\text { Coefficients }\end{array}$} & \multirow{2}{*}{$\begin{array}{c}\text { Standardized } \\
\text { Coefficients } \\
\text { Beta } \\
\end{array}$} & \multirow[t]{2}{*}{$\mathrm{t}$} & \multirow[t]{2}{*}{ Sig. } \\
\hline & $\mathrm{B}$ & Std. Error & & & \\
\hline (Constant) & 2,397 & 2,381 & & 1,007 & 318 \\
\hline Pemahaman Akuntansi & 280 &, 050 &, 423 & 5,656 &, 000 \\
\hline Pemanfaatan SIA & 358 &, 058 & 457 & 6,130 &, 000 \\
\hline Sistem Pengendalian Intern &, 114 &, 031 & 266 & 3,624 &, 001 \\
\hline
\end{tabular}

a. Dependent Variable: Kualitas Laporan Keuangan

Uji statistik $\mathrm{t}$ bertujuan untuk menguji

Berdasarkan hasil pengolahan data dengan SPSS maka persamaan regresi linier berganda yang didapatkan adalah sebagai berikut:

$\mathrm{Y}=2,397+0,280 \mathrm{X} 1+0,358 \mathrm{X} 2+0,114 \mathrm{X} 3+\mathrm{e}$

Persamaan regresi linier berganda di atas dapat diartikan bahwa Konstanta sebesar 2,397 menyatakan bahwa apabila tidak ada perubahan nilai variabel bebas yaitu pemahaman akuntansi, pemanfaatan sistem informasi akuntansi, sistem pengendalian intern maka variabel terikat yaitu kualitas laporan keuangan akan mengalami kenaikan sebesar 2,397. Koefisien regresi X1 sebesar 0,280, menyatakan bahwa jika pemahaman akuntansi (X1) naik 1 satuan, maka kualitas laporan keuangan (Y) akan meningkat sebesar 0,280 dengan asumsi variabel lainnya konstan. Koefisien regresi X2 sebesar 0,358, menyatakan bahwa jika pemanfaatan sistem informasi akuntansi (X2) naik 1 satuan, maka kualitas laporan keuangan (Y) akan meningkat sebesar 0,358 asumsi variabel lainnya konstan. Koefisien regresi X3 sebesar 0,114, menyatakan bahwa jika sistem pengendalian intern (X3) naik 1 satuan, maka kualitas laporan keuangan (Y) akan meningkat sebesar 0,114 asumsi variabel lainnya konstan.

\section{Uji Statistik t (t-test)}

seberapa jauh pengaruh satu variabel independen secara individual dalam menerangkan variasi variabel dependen (Sudaryono, 2017). Berdasarkan hasil analisis pada Tabel 4, menunjukkan bahwa nilai koefisien dari variabel pemahaman akuntansi (X1) bernilai positif yaitu 0,280 dengan nilai signifikan 0,000 . Hal ini berarti bahwa hipotesis pertama yang menyatakan pemahaman akuntansi berpengaruh terhadap kualitas laporan keuangan diterima. Nilai koefisien variabel pemanfaatan sistem informasi akuntansi (X2) bernilai positif sebesar 0,358 dengan nilai signifikan 0,000 . Hal ini berarti bahwa hipotesis kedua yang menyatakan pemanfaatan sistem informasi akuntansi berpengaruh terhadap kualitas laporan keuangan diterima. Nilai koefisien variabel sistem pengendalian intern (X3) bernilai positif sebesar 0,114 dengan nilai signifikan 0,001 . Hal ini berarti bahwa hipotesis ketiga yang menyatakan sistem pengendalian intern berpengaruh terhadap kualitas laporan keuangan diterima.

\section{Uji Statistik F (F-test)}

Uji statistik F dilakukan dengan tujuan untuk menguji apakah semua variabel independen yang dimaksud dalam model mempunyai pengaruh secara bersama-sama terhadap variabel dependen (Ghozali, 2013).

Tabel 6

Hasil Uji Determinasi

\begin{tabular}{ccccc}
\hline \multicolumn{4}{c}{ Model Summary } \\
\hline Model & $\mathrm{R}$ & R Square & $\begin{array}{c}\text { Adjusted } \mathrm{R} \\
\text { Square }\end{array}$ & $\begin{array}{c}\text { Std. Error of the } \\
\text { Estimate }\end{array}$ \\
\hline 1 &, $861^{\mathrm{a}}$ &, 741 &, 727 & 1,919 \\
\hline \multicolumn{3}{c}{ a. Predictors: (Constant), Sistem Pengendalian Intern, Pemanfaatan SIA, } \\
Pemahaman Akuntansi
\end{tabular}



terhadap Kualitas Laporan Keuangan

Berdasarkan Tabel 6, diketahui bahwa nilai adjusted-R2 sebesar 0,727 , yang mengandung arti bahwa $72,7 \%$ variasi besarnya kualitas laporan keuangan dapat dijelaskan oleh variasi pemahaman akuntansi, pemanfaatan sistem informasi akuntansi, dan sistem pengendalian intern. Sedangkan sisanya $27,3 \%$ dipengaruhi oleh variabel dari luar model.

\section{Pembahasan Hasil Penelitian}

Berdasarkan data hasil penelitian melalui berbagai pengujian, maka dapat dihasilkan pembahasan data sebagai berikut:

Pengaruh Pemahaman Akuntansi terhadap Kualitas Laporan Keuangan di BPKAD Kabupaten Badung

Hasil penelitian menunjukkan bahwa pemahaman akuntansi berpengaruh terhadap kualitas laporan keuangan di BPKAD Kabupaten Badung, sehingga hipotesis pertama diterima. Pemahaman akuntansi berpengaruh positif terhadap kualitas laporan keuangan di BPKAD Kabupaten Badung mempunyai arti bahwa semakin baik pemahaman akuntansi yang dimiliki oleh pegawai maka semakin baik pula kualitas laporan keuangan yang akan dihasilkan. Hasil ini sejalan dengan hasil penelitian (Yuliani et al., 2010) dan (Diani, 2014) yang menyatakan bahwa pemahaman akuntansi yang dimiliki oleh pegawai berpengaruh terhadap kualitas laporan keuangan pemerintah daerah.

Pengaruh Pemanfaatan Sistem Informasi Akuntansi terhadap Kualitas Laporan Keuangan di BPKAD Kabuaten Badung

Hasil penelitian menunjukkan bahwa pemanfaatan sistem infromasi akuntansi berpengaruh terhadap kualitas laporan keuangan di BPKAD Kabupaten Badung, sehingga hipotesis kedua diterima. Pemanfaatan sistem informasi akuntansi berpengaruh positif terhadap kualitas laporan keuangan di BPKAD Kabupaten Badung mempunyai arti bahwa semakin tinggi pemanfaatan sistem informasi akuntansi maka semakin baik pula kualitas laporan keuangan yang dihasilkan. Hal ini menunjukkan bahwa pemanfaatan sistem informasi akuntansi pada BPKAD Kabupaten Badung sudah dimanfaatkan secara maksimal. Hasil ini sejalan dengan penelitian (Silviana, 2014) dan (Rahayu, 2015) yang menyatakan bahwa pemanfaatan sistem informasi akuntansi beperngaruh positif terhadap kualitas laporan keuangan pemerintah daerah.

Pengaruh Sistem Pengendalian Intern terhadap Kualitas Laporan Keuangan di BPKAD Kabupaten

\section{Badung}

Hasil penelitian menunjukkan bahwa sistem pengendalian intern berpengaruh terhadap kualitas laporan keuangan di BPKAD Kabupaten Badung, sehingga hipotesis ketiga diterima. Sistem pengendalian intern berpengaruh positif terhadap kualitas laporan keuangan di BPKAD Kabupaten Badung mempunyai arti bahwa semakin baik sistem pengendalian intern dilaksanakan maka semakin baik pula kualitas laporan keuangan yang dihasilkan. Hasil ini sejalan dengan penelitian (Artana, 2016) yang menyatakan bahwa sistem pengendalian intern berpengaruh signifikan terhadap kualitas laporan keuangan pemerintah daerah.

Pengaruh pemahaman akuntansi, pemanfaatan sistem informasi akuntansi, dan sistem pengendalian intern terhadap kualitas laporan keuangan di BPKAD Kabupaten Badung

Hasil penelitian menunjukkan bahwa pemahaman akuntansi, pemanfaatan sistem informasi akuntansi, dan sistem pengendalian intern berpengaruh terhadap kualitas laporan keuangan di BPKAD Kabupaten Badung diterima. Hal ini mempunyai arti bahwa kualitas laporan keuangan dipengaruhi oleh pemahaman akuntansi yang dimiliki oleh pegawai, selain itu untuk dapat mempermudah suatu pekerjaan diperlukan pemanfaatan sistem informasi akuntansi dan diperlukan suatu sistem pengendalian intern dalam mencegah suatu kecurangan dan mengidentifikasi resiko-resiko yang mungkin saja terjadi. Maka dapat disimpulkan bahwa semakin baik pemahaman akuntansi, pemanfaatan sistem informasi akuntansi, dan sistem pengendalian intern yang dimiliki pemerintah, semakin baik pula kualitas laporan keuangan yang dihasilkan.

Menurut (Mardiana \& Fahlevi, 2017) menunjukkan bahwa pemahaman akuntansi dan pengendalian intern secara bersama-sama berpengaruh terhadap kualitas laporan keuangan pemerintah. Menurut (Antika, 2013) pemahaman akuntansi, pemanfaatan sistem akuntansi keuangan daerah, kompetensi sumber daya manusia dan efektivitas pengendalian internal berpengaruh secara simultan terhadap kualitas laporan keuangan.

\section{SIMPULAN}

Berdasarkan hasil pengolahan data dan pembahasan yang telah diuraikan sebelumnya, maka dapat disimpulkan bahwa Pemahaman 
akuntansi terhadap kualitas laporan keuangan di Badan Pengelola Keuangan dan Aset Daerah Kabupaten Badung berpengaruh signifikan terhadap kualitas laporan keuangan dengan nilai signifikan 0,000. Pemanfaatan sistem informasi akuntansi berpengaruh signifikan terhadap kualitas laporan keuangan dengan nilai signifikan 0,000. Sistem Pengendalian Intern berpengaruh signifikan terhadap kualitas laporan keuangan dengan nilai signifikan 0,001. Pemahaman akuntansi, pemanfaatan sistem informasi akuntansi, dan sistem pengendalian intern berpengaruh signifikan terhadap kualitas laporan keuangan dengan nilai signifikan 0,000. Adapun, untuk meningkatkan kualitas laporan keuangan pemerintah, sebaiknya dinas lebih memperhatikan pegawainya untuk bisa memahami akuntansi, pemanfaatan sistem informasi akuntansi, dan sistem pengendalian intern dengan memberikan sosialisasi, pendidikan, dan pelatihan yang intensif bagi pegawai yang bertanggungjawab langsung atas penyusunan dan penyajian laporan keuangan, sehingga mampu membuat laporan keuangan yang berkualitas.

\section{DAFTAR PUSTAKA}

Afifah, N. N. (2009). Akuntansi Pemerintah: Implementasi Akuntansi Keuangan Pemerintah Daerah. Jakarta: Kencana Prenada Media Group.

Antika, Y. R. N. (2013). Pengaruh Pemahaman Akuntansi, Pemanfaatan Sistem Akuntansi Keuangan Daerah, Kompetensi Sumber Daya Manusia dan Efektivitas Pengendalian Internal Terhadap Efektivitas Pengelolaan Keuangan Daerah Pemerintah Provinsi Kepualuan Riau. Universitas Maritim Raja Ali Haji. Retrieved from http://jurnal.umrah.ac.id/wp-content/ uploads/gravity_forms/1-

ec61c9cb232a03a96d0947c6478e525e/2017/08/ JURNAL10.pdf

Artana, A. S. (2016). Pengaruh Pemahaman Standar Akuntansi Pemerintah, Pemanfataan Sistem Informasi Akuntansi Keuangan Daerah Dan Sistem Pengendalian Internal Terhadap Kualitas Laporan Keuangan Pemerintah Daerah. Program Studi Akuntansi Fakultas Ekonomi Dan Bisnisuniversitas Islam Negeri Syarif Hidayatullah Jakarta. Retrieved from http://repository.uinjkt.ac.id/dspace/ bitstream/123456789/33210/1/ARLIA SARI ARTANA.pdf

Diani, D. I. (2014). Pengaruh Pemahaman Akuntansi, Pemanfaatan Sistem Informasi Akuntansi Keuangan Daerah Dan Peran Internal Audit Terhadap Kualitas Laporan Keuangan Pemerintah Daerah (Studi Empiris pada Satuan Kerja Perangkat Daerah di Kota Pariaman). Jurnal Akuntansi, 2(1), 1-23. Retrieved from http://ejournal.unp.ac.id/students/index.php/akt/ article/view/897

Ghozali, I. (2013). Aplikasi Analisis Multivariate dengan Program SPSS. Jakarta: Salemba Empat.
Information Systems, organization and Technology in The Networked Enterpise. New Jersey: PrenticeHall.

Mardiana, R., \& Fahlevi, H. (2017). Pengaruh Pemahaman Akuntansi, Pengendalian Internal dan Efektivitas Penerapan Sap Berbasis Akrual terhadap Kualitas Laporan Keuangan (Studi pada Satuan Perangkat Kerja Kota Banda Aceh). Jurnal Ilmiah Mahasiswa Ekonomi Akuntansi Fakultas Ekonomi Dan Bisnis Universitas Syiah Kuala, 2(2), 30-38. Retrieved from https://doi.org/10.24815/jimeka.v2i2.3167

Peraturan Pemerintah Nomor 71 Tahun 2010. Standar Akuntansi Pemerintah. www.google.com. Diunggah tanggal 22 September 2017.

Peraturan Pemerintah Nomor 56 Tahun 2005, tentang Sistem Informasi Keuangan Daerah. www.google.com. Diunggah tanggal 22 September 2017.

Poerwadaminta. (2006). Kamus Umum Bahasa Indonesia. Pusat Bahasa Departemen Pendidikan Nasional. Edisi Ketiga. Jakarta: Balai Pustaka.

Rahayu, M. W. (2015). Pengaruh Penerapan Sistem Informasi Akuntansi Terhadap Kualitas Laporan Keuangan. Universitas Pendidikan Indonesia. Retrieved from http://repository.upi.edu

Saputra, A., Satriawan, R. A., \& Supriono. (2015). Pengaruh Penerapan Standar Akuntansi Pemerintahan, Sistem Pengendalian Intern Dan Kompetensi Sumber Daya Manusia Terhadap Kualitas Laporan Keuangan (Studi Pada Satuan Kerja Perangkat Daerah Kabupaten Kampar). Jurnal Online Mahasiswa (JOM) Fakultas Ekonomi Universitas Riau, 2(2), 115. Retrieved from https://jom.unri.ac.id/index.php/ JOMFEKON/article/view/8834

Silviana, A. E. (2014). Pengaruh Penerapan Sistem Informasi Akuntansi Terhadap Kualitas Laporan Keuangan Pemerintah Daerah Survey Pada Pemerintah Kabupaten Di Seluruh Jawa Barat. Jurnal Nasional Dosen Universitas Widyatama, 6(1), 24-36. Retrieved from http://repository.widyatama.ac.id/ xmlui/handle/123456789/7301

Sudaryono. (2017). Metodologi Penelitian. Jakarta: Rajawali Pers.

Winidyaningrum, C., \& Rahmawati. (2009). Pengaruh Sumber Daya Manusia Dan Pemanfaatan Teknologi Informasi Terhadap Keterandalan Dan Ketepatwaktuan Pelaporan Keuangan Pemerintah Daerah Dengan Variabel Intervening Pengendalian Intern Akuntansi (Studi Empiris Di Pemda Subosukawonosraten). In Simposium Nasional Akuntansi XIII. Retrieved from http://stiepena.ac.id/ wp-content/uploads/2011/11/ASP_18.pdf

Yuliani, S., Nadirsyah, \& Bakar, U. (2010). Pengaruh Pemahaman Akuntansi, Pemanfaatan Sistem Informasi Akuntansi Keuangan Daerah Dan Peran Internal Audit Terhadap Kualitas Laporan Keuangan Pemerintah Daerah (Studi pada Pemerintah Kota Banda Aceh). Jurnal Telaah Riset Akuntansi, 3(2), 206-220. Retrieved from http://jurnal.unsyiah.ac.id/ TRA/article/view/340 